\section{INHIBITION OF REVERSE TRANSCRIPTASE BY LIMOCROCIN}

\author{
Sakiko Hanajima, Kurumi Ishimaru, \\ Katsu-ichi Sakano ${ }^{\dagger}$, Swapan Kumar Roy, \\ Yoshio INOUYE and SHOSHIRO NAKAMURA \\ Institute of Pharmaceutical Sciences, \\ Hiroshima University, School of Medicine, \\ Kasumi, Minami-ku, \\ Hiroshima 734, Japan
}

(Received for publication December 13, 1984)

Reverse transcriptase in oncogenic RNA virion may play a critical role in the integration of viral genomes into host cell DNA and viral tumorigenesis ${ }^{1,2)}$. The specific inhibitor against the enzyme might be a candidate for the chemotherapeutic agent of viral oncogenesis. Thus, we have been screening for Streptomyces metabolites inhibiting reverse transcriptase of avian myeloblastosis virus (AMV) and reported the inhibitor, named retrostatin, in the previous paper $^{3)}$. In the course of screening for the enzyme inhibitors, the precipitate of the broth filtrate of Isolate H 1180 MY-18 at acidic pH showed strong inhibition against the enzyme. The active component was purified by silica gel column chromatography and the free acid of the inhibitor was recovered as a red amorphous powder. The molecular formula and physicochemical properties of the inhibitor were identical with those of limocrocin ${ }^{4,5)}$. Limocrocin was reported as the pigment produced by Streptomyces limosus. Since biological activity of limocrocin had not been reported in the literatures, we studied the inhibitory activities of limocrocin against various kinds of DNA and RNA polymerases. The results are described in this paper.

Materials

Purified reverse transcriptase of AMV (specific activity: $50,000 \mathrm{U} / \mathrm{mg}$ protein) was obtained from Life Science Inc. DNA-directed DNA polymerase I of Escherichia coli, DNA-directed RNA polymerase of E. coli ( $400 \mathrm{U} /$ vial), DNA-directed DNA polymerase of calf thymus $(50 \mathrm{U} /$ vial $)$, calf thymus DNA, poly-(rA) and oligo-(dT) $)_{12 \sim 18}$ were products of P.L. Biochemicals, Inc. $\left[{ }^{3} \mathrm{H}\right]$ TTP

† Present address: Central Research Institute, Dai-ichi Pharmaceutical Co., 1-16-13 Kitakasai, Edogawa-ku, Tokyo, Japan.
Table 1. Antimicrobial spectrum of limocrocin.

\begin{tabular}{lc}
\hline \multicolumn{1}{c}{ Test microbe } & MIC $(\mu \mathrm{g} / \mathrm{ml})$ \\
\hline Staphylococcus aureus FDA 209 P & 100 \\
Micrococcus flavus FDA 16 & 100 \\
M. lysodeikticus & $>200$ \\
M. luteus PCI 1001 & 100 \\
Bacillus subtilis PCI 219 & $>200$ \\
B. anthracis & 12.5 \\
Corynebacterium bovis 1810 & 100 \\
Mycobacterium phlei & $>200$ \\
Escherichia coli NIHJ & $>200$ \\
Shigella sonnei $191-66$ & $>200$ \\
Proteus vulgaris OX 19 & $>200$ \\
Klebsiella pheumoniae & $>200$ \\
Salmonella typhosa T-63 & $>200$ \\
Serratia marcescens & $>200$ \\
Candida albicans Yu-1200 & $>200$ \\
C. krusei NI 7492 & $>200$ \\
Saccharomyces cerevisiae & $>200$ \\
\hline
\end{tabular}

$(43 \mathrm{Ci} / \mathrm{mmol})$ and $\left[{ }^{3} \mathrm{H}\right] \mathrm{UTP}(10.1 \mathrm{Ci} / \mathrm{mmol})$ were purchased from Amersham-Searle, Inc. and unlabeled nucleotides were products of Sigma Chemical Co. All other chemicals used were of analytical grade.

Assay Method to Determine Reverse Transcriptase Activity

The method reported by NisHio et al. ${ }^{3)}$ was modified to determine reverse transcriptase activity as described below: An assay solution was composed of $80 \mathrm{~mm}$ Tris-HCl buffer ( $\mathrm{pH} 8.0$ ), $5 \mathrm{mM} \mathrm{MgCl}_{2}, 60 \mathrm{~mm} \mathrm{NaCl}, 6 \mathrm{~mm}$ dithiothreitol, $0.02 \mathrm{mM}\left[{ }^{3} \mathrm{H}\right] \mathrm{TTP}(12.5 \mu \mathrm{Ci} / \mathrm{ml})$, poly-(rA) $(4 \mu \mathrm{g} /$ $\mathrm{ml})$, oligo-(dT) $)_{12 \sim 18}(200 \mathrm{ng} / \mathrm{ml})$, bovine serum albumin $(200 \mu \mathrm{g} / \mathrm{ml})$ and reverse transcriptase of AMV $(2.0 \mathrm{U} / \mathrm{ml})$. A test sample was dissolved in $20 \mathrm{~mm}$ Tris- $\mathrm{HCl}$ buffer $(\mathrm{pH} 8.0)$ to prepare a test solution. A mixture of the assay solution $(50 \mu \mathrm{l})$ and the test solution $(50 \mu \mathrm{l})$ was incubated at $37^{\circ} \mathrm{C}$ for 1 hour and the incubation was terminated by cooling in an ice bath. The resulting mixture was soaked into a $2.4 \mathrm{~cm}$-round piece of filter paper previously treated with $0.1 \mathrm{M}$ pyrophosphate solution and dried. The filter paper was washed three times with $10 \%$ TCA, subsequently washed once with ethanol and dried. The radioactivity of the acid insoluble fraction remaining on the filter paper was measured in a toluene-based scintillation cocktail.

Assay Method to Determine DNA-Directed DNA Polymerase Activity

The method reported by RICHARDSON et al. ${ }^{6)}$ 
Fig. 1. Effects of limocrocin and adriamycin on various RNA- or DNA-directed DNA and RNA polymerases.

RNA-Directed DNA polymerase of AMV, DNA-directed RNA polymerase of E. coli, $\Delta$ DNA-directed DNA polymerase I of $E$. coli, $\mathbf{\Delta}$ DNA-directed DNA polymerase of calf thymus.

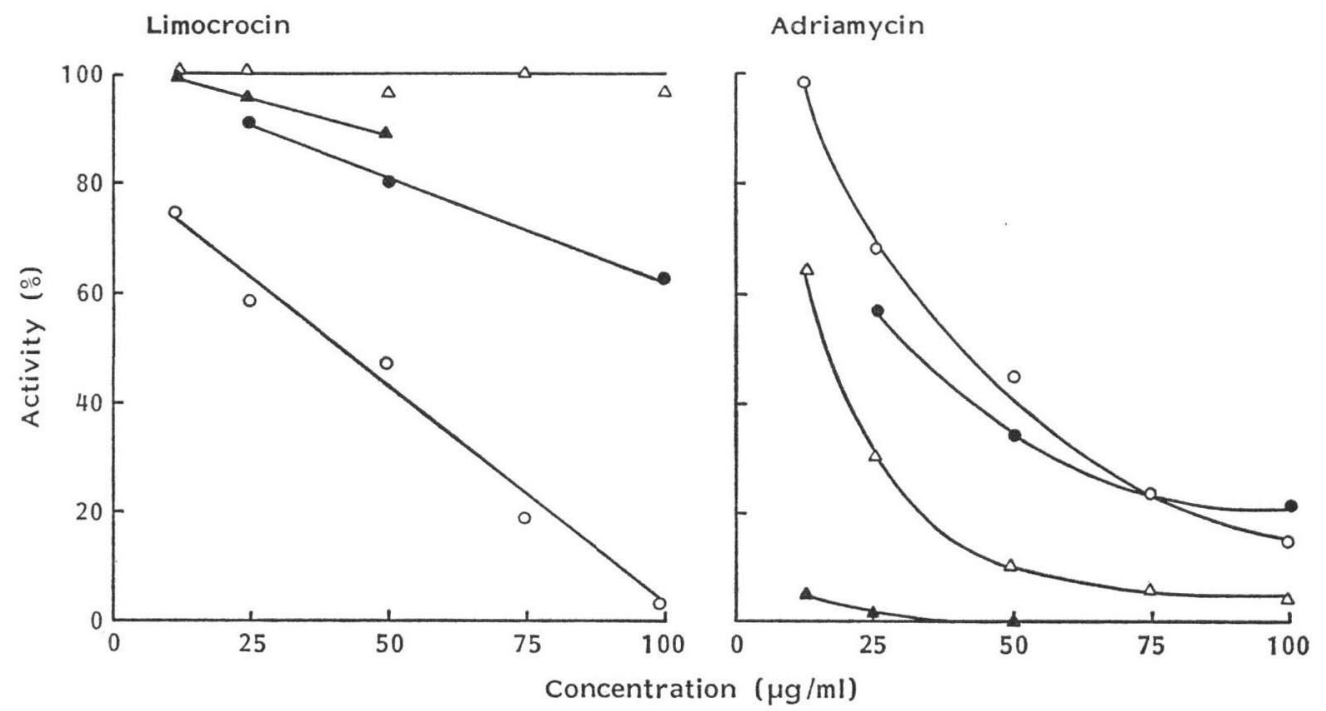

was modified to determine DNA-directed DNA polymerase activity as described below: An assay solution was composed of $80 \mathrm{~mm}$ glycine$\mathrm{NaOH}$ buffer ( $\mathrm{pH}$ 9.2), $10 \mathrm{~mm} \mathrm{MgCl}_{2}, 1.4 \mathrm{~mm}$ dithiothreitol, $40 \mu \mathrm{M}$ each of dATP, dCTP, dGTP and $\left[{ }^{3} \mathrm{H}\right] \mathrm{TTP}(0.70 \mu \mathrm{Ci} / \mathrm{ml})$, activated calf thymus DNA $(50 \mu \mathrm{g} / \mathrm{ml})$, yeast RNA $(200 \mu \mathrm{g} / \mathrm{ml})$ and DNA-directed DNA polymerase I of $E$. coli $(12.5 \mathrm{U} / \mathrm{ml})$ or calf thymus DNA-directed DNA polymerase $(30.0 \mathrm{U} / \mathrm{ml})$. A mixture of the assay solution $(50 \mu \mathrm{l})$ and the test sample dissolved in $20 \mathrm{~mm}$ glycine- $\mathrm{NaOH}$ buffer $(\mathrm{pH} \mathrm{9.2,} 50 \mu \mathrm{l})$ was incubated at $37^{\circ} \mathrm{C}$ for 30 minutes and the resulting mixture was treated with the same procedures described above to measure the radioactivity of the acid insoluble fraction.

Assay Method to Determine DNA-Directed RNA Polymerase Activity

DNA-Directed RNA polymerase activity was determined as described below: An assay solution was composed of $80 \mathrm{~mm}$ Tris- $\mathrm{HCl}$ buffer (pH 7.9), $20 \mathrm{~mm} \mathrm{MgCl}_{2}, 0.2 \mathrm{~mm}$ EDTA, $0.2 \mathrm{~mm}$ dithiothreitol, $0.8 \mathrm{~mm} \mathrm{~K}_{2} \mathrm{HPO}_{4}, 0.3 \mathrm{~mm}$ each of ATP, CTP and GTP, $0.03 \mathrm{~mm}\left[{ }^{3} \mathrm{H}\right]$ UTP $(0.32$ $\mu \mathrm{Ci} / \mathrm{ml})$, bovine serum albumin $(1.0 \mathrm{mg} / \mathrm{ml})$, calf thymus DNA $(0.3 \mathrm{mg} / \mathrm{ml})$ and DNA-directed RNA polymerase of $E$. coli $(180 \mathrm{U} / \mathrm{ml})$. A mixture of the assay solution $(50 \mu 1)$ and the test sample dissolved in $20 \mathrm{~mm}$ Tris- $\mathrm{HCl}$ buffer (pH 7.9) was incubated at $37^{\circ} \mathrm{C}$ for 10 minutes and the resulting mixture was treated with the same procedures described above to measure the radioactivity of the acid insoluble fraction.

The antimicrobial activity was determined by the agar dilution method on glucose nutrient agar and the inhibitor (=limocrocin) showed very weak antimicrobial activity against only a few of Gram-positive bacteria as seen in Table 1 . Both limocrocin and adriamycin showed 50\% inhibition against reverse transcriptase of AMV at a concentration of about $50 \mu \mathrm{g} / \mathrm{ml}$, as seen in Fig. 1. $\mathrm{ID}_{50}$ of adriamycin against DNAdirected DNA or RNA polymerase of $E$. coli or DNA-directed DNA polymerase of calf thymus was less than $50 \mu \mathrm{g} / \mathrm{ml}$. Nevertheless, ID $_{50}$ of limocrocin against those polymerases were more than $100 \mu \mathrm{g} / \mathrm{ml}$. The inhibitory activity of limocrocin against reverse transcriptase of AMV was not affected by changing of concentration of the template-primer, the substrate or the carrier protein, but significantly reduced when the concentration of reverse transcriptase of AMV was increased, as seen in Table 2. Thus, limocrocin was considered to be a specific enzyme inhibitor against reverse transcriptase of AMV.

To date, adriamycin ${ }^{7)}$, daunomycin ${ }^{7)}$, strep- 
Table 2. Effects of limocrocin on reverse transcriptase of AMV at various concentrations of template-primer, substrate, enzyme and carrier protein.

1) Effect of concentration of template-primer.

\begin{tabular}{ccc}
\hline Poly-(rA) $(\mu \mathrm{g} / \mathrm{ml})$ & $\begin{array}{c}\text { Oligo-(dT) } \\
(\mathrm{U} / \mathrm{ml})\end{array}$ & $\begin{array}{c}\text { Inhibition } \\
(\%)\end{array}$ \\
\hline 8 & 0.04 & 61.9 \\
$2^{*}$ & 0.01 & 62.2 \\
0.4 & 0.002 & 59.5 \\
\hline
\end{tabular}

2) Effect of concentration of substrate.

\begin{tabular}{cc}
\hline $\mathrm{dTTP}(\mu \mathrm{M})$ & Inhibition $(\%)$ \\
\hline 100 & 59.4 \\
25 & 58.1 \\
$10^{*}$ & 61.0 \\
2.5 & 59.4 \\
1.0 & 62.0 \\
\hline
\end{tabular}

3) Effect of concentration of enzyme.

\begin{tabular}{cc}
\hline Enzyme $(\mathrm{U} / \mathrm{ml})$ & Inhibition $(\%)$ \\
\hline 4 & 33.9 \\
2 & 50.5 \\
$1^{*}$ & 72.9 \\
\hline
\end{tabular}

4) Effect of concentration of carrier protein.

\begin{tabular}{cc}
\hline BSA $(\mu \mathrm{g} / \mathrm{ml})$ & Inhibition $(\%)$ \\
\hline $100^{*}$ & 69.8 \\
25 & 69.2 \\
\hline
\end{tabular}

* Standard reaction mixture.

Limocrocin was used at a concentration of $50 \mu \mathrm{g} / \mathrm{ml}$.

tonigrin $^{3)}$ and the streptovaricins ${ }^{\theta)}$ have been reported to inhibit reverse transcriptase. Nevertheless, these antibiotics have been also reported to show strong antimicrobial activity and to inhibit primarily DNA-directed DNA, DNAdirected RNA or both of the polymerases. While, revistin ${ }^{10)}$, retrostatin ${ }^{3)}$ and limocrocin are considered to be specific enzyme inhibitors against reverse transcriptase.

\section{Acknowledgment}

This work was supported in part by a Grant-in-Aid for Cancer Research from the Ministry of Education, Science and Culture, Japan, which is gratefully ac- knowledged. We wish to express our appreciation to Dr. Kazutoshi Mizoue, Taisho Pharmaceutical Co., Ltd., for his helpful suggestions.

\section{References}

1) Temin, H. M.: The RNA tumor virusesbackground and foreground. Proc. Natl. Acad. Sci. USA 69: 1016 1020, 1972

2) Verma, I. M.: The reverse transcriptase. Biochim. Biophys. Acta 473: 1 38, 1977

3) Nishio, M.; A. Kuroda, M. Suzuki, K. IshiMARU, S. NAKAmURA \& R. Nomi: Retrostatin, a new specific enzyme inhibitor against avian myeloblastosis virus reverse transcriptase. J. Antibiotics 36: $761 \sim 769,1983$

4) Brockmann, H. \& G. Grothe: Über Actinomycetenfarbstoffe. II. Limocrocin, ein gelber Actinomycetenfarbstoff. Chem. Ber. 86:1110 1115, 1953

5) Brockmann, H.; H. U. May, W. Lenk \& H. Brockmann, Jr.: Actinomyceten-farbstoffe. X. Die Konstitution des Limocrocins. Chem. Ber. 102: $3217 \sim 3223,1969$

6) Richardson, C. C.; C. L. Schildkraut, H. V. Aposhian \& A. Kornberg: Enzymatic synthesis of deoxyribonucleic acid. J. Biol. Chem. 239: $222 \sim 232,1964$

7) Chandra, P.; F. Zunino, A. Götz, D. Gericke, R. Thorbeck \& A. D. Marco: Specific inhibition of DNA-polymerases from RNA tumor viruses by some new daunomycin derivatives. FEBS Lett. $21: 264 \sim 268,1972$

8) Chirigos, M. A.; J. W. Pearson, T. S. Papas, W. A. Woods, H. B. Wood, Jr. \& G. Spahn: Effect of streptonigrin and analogs on oncornavirus replication and DNA polymerase activity. Cancer Chem. Rep. 57: 305 309, 1973

9) Brockman, W. W.; W. A. Carter, L. H. Li, F. REUSSER \& F. R. NICHOL: Streptovaricins inhibit RNA dependent DNA polymerase present in an oncogenic RNA virus. Nature 230: 249 250, 1971

10) Numata, M.; K. Nitta, R. Utahara, K. MaEDA \& H. UMEZAWA: Revistin found by screening for inhibitors of reverse transcriptase of an oncogenic virus. J. Antibiotics 28: 757 763,1975 